\title{
MENINGKATKAN KEMAMPUAN MOTORIK KASAR MELALUI PERMAINAN TRADISIONAL LOMPAT TALI PADA USIA 5-6 TAHUN DI PAUD TUNAS MEKAR PLUS TAHUN PELAJARAN 2017/2018
}

\author{
SUHARTINI \\ PG PAUD, FKIP, Universitas Widya Gama Mahakam Samarinda \\ ( Artiniku@yahoo.com ) \\ JARWOKO \\ PG PAUD, FKIP, Universitas Widya Gama Mahakam Samarinda \\ ( jarwoko19@gmail.com )
}

\begin{abstract}
ABSTRAK
The researcher conducted a classroom action research to improve students gross motor skill, especially for the physical motor skill such as strength and balance through traditional game jumping rope. This study was conducted in group B at Tunas MekarPlus Playgroup and involved thirteen students as the research subjects. Moreover, two cycles were applied in this study with three meeting in each cycle. To collect the data, observation and documentation were employed. In addition, the data was analyzed through mean score analysis by determining the progress of students' gross motor skill in each cycle which then displayed in table for better understanding. Having analyzed the data, students' average score in cycle 1 was $47 \%$ and then increased into $80 \%$ in cycle 2 . It shows that students' gross motor skill has developed as expected, i.e.: ability to jump. Regarding to the strength, students have reached the targeted standard, i.e.; $60 \%-79 \%$, classified in 'develop as expected'.
\end{abstract}

Key words: gross motor skill, jumping rope

\section{PENDAHULUAN}

Pendidikan anak usia merupakan salah satu pendidikan yang diterapkan sejak anak di dalam kandungan sampai lahir. Jadi anak usia dini merupakan anak yang berusiaantara 0-6 tahun. yang menurut direktorat pendidikan anak usia dini, anak usia dini adalah anak usia 0-6 tahun,baik yang terlayani maupun yang tidak terlayani di lembaga pendidikan anak usia dini. NAEYC (Natonal Association Education For Young Children) dalam Sofia Hartati (2005:7) menyebutkan bahwa: "anak usia dini adalah sekelompok individu yang berada pada rentang usia antara 0-8 tahun. menurut definisi ini anak usia dini merupakan kelompok manusia yang berada dalam proses pertumbuhan dan perkembangan hal ini mengisyaratkan bahwa anak usia dini adalah individu yang unik dimana ia memiliki pola pertumbuhan dan kemampun dalam aspek fisik, koknitif, socialemosional, kreatifitas, bahasa, dan komunikasi yang khusus sesui dengan tahapan yang 
dilalui oleh anak tersebut." Undangundang Nomor 20 Tahun 2003 tentang sistem Pendidikan Nasional Pasal 1 angka 14 menyatakan bahwa pendidikan anak usia dini adalah suatu upaya pembinaan yang ditujukan kepada anak sejak lahir sampai dengan usia enam tahun yang dilakukan melalui pemberian rangsangan pendidikan untuk membantu pertumbuhan dan perkembangan jasmani dan rohani, agar anak memiliki kesiapan dalam memasuki pendidikan lebih lanjut, baik pendidikan secara formal di sekolah maupun secara nonformal.

Motorik kasar erat kaitannya dengan pertumbuhan dan perkembangan anak usia dini (PAUD). Kemampuan fisik yang baik akan menunjang kemampuan motorik kasar maupun motorik halus anak. Motorik kasar merupakan gerakangerakan yang melibatkan otot-otot besar anak baik kaki maupun tangan. Menurut Santrock (Nelva Rolina, 2012: 16), motorik kasar (gross motor skill) meliputi kegiatan otototot besar seperti menggerakkan lengan dan berjalan, sementara itu motorik halus meliputi gerakan-gerakan menyesuaikan secara lebih halus seperti ketangkasan jari. Perkembangan motorik saling merupakan perubahan gerakan kemampuan gerak bayi dari lahir sampai dengan dewasa yang melibatkan aspek dan perilaku gerak. Menurut Sumantri (2005: 271), motorik kasar merupakan keterampilan yang bercirikan gerak yang melibatkan sekelompok otot-otot besar sebagai dasar utama gerakannya. Santrock (2009: 209) menyatakan bahwa keterampilan motorik kasar (gross motor skill) merupakan keterampilan yang melibatkan aktivitas otot besar seperti tangan seseorang untuk bergerak dan berjalan, sedangkan menurut Bambang Sujiono (2005: 1.13) gerakan motorik kasar adalah kemampuan yang membutuhkan koordinasi sebagian besar bagian tubuh anak gerakan ini memerlukan tenaga karena dilakukan oleh otot-otot anak yang tertentu yang dapat membuat mereka meloncat, memanjat, berlari, menaiki sepeda roda tiga, serta berdiri dengan satu kaki. Menurut Amisisilia sari (2012) motorik kasar adalah bagian dari aktivitas motorik yang mencakup keterampilan otot-otot besar, gerakan ini lebih menuntut kekuatan fisik dan keseimbangan, geakan motorik kasar melibat kan aktivitas otot tangan, kaki, dan seluruh anak, gerakan ini mengandal kan kematangan dalam koordinasi, berbagai gerakan motorik kasar yang di capai ank sangat beguna bagi kehidupannyakelak, seperti, merangkak, berjalan, berlari, melompatatau berenang.

Novi Mulyani (2016:78) permainan tradisional lompat tali dapat melatih. kemampuan motorik kasar anak,. Dalam 
permaian ini , anak akan belajar cara atau teknik melompat yang baik, cara mendarat yang baik, mengukur tinggi lompatan, dan sebagainya. Inilah yang akan membuat anak tumbuh menjadi cekatan,berisi, kuat, serta terlatih. Lompat tali juga bisa mengurangi obesitas pada anak. Selain itu, emosi anak turut ikut dilatih, yakni keberanian untuk melakukan lompatan yang tantangannya semaki tinggi. Dalm permainan lompat tinggi secara kelompok, anak membutuhkan teman hingga memberi kesempatan untuk bersosialisasi. Ia juga dapat belajar empati, bergiliran, menaati peraturan, dan lain-lain.

Bermain dilakukan sambil belajar dilakukan dengan rileks tanpa paksaan sehingga menjadi suatu yang menyenangkan. Taman Kanak-Kanak (TK) harus membimbing dan mengawasi anak dalam melakukan setiap gerakan yang dilakukan oleh anak dalam bermain sehingga semua aspek perkembangan dapat berkembang secara optimal. PAUD Tunas Mekar Plus kelompok B dengan jumlah 13 siswa yang terdiri dari laki-laki 7 dan 6 perempuan motorik kasar anak masih rendah. Dengan ratarata nilai 50-55 dengan kreteria kurang atau belum berkembang, dan hanya beberapa anak saja yang dapat dikatakan kemampuan motorik kasarnya berkembang sesuai harapan dengan nilai rata-rata 70-75 dengan nilai baik atau berkembang sesuai harapan. Faktanya anak belum dapat mengontrol gerak tubuh atau mengkoordinasikan seluruh anggota tubuhnya secara terampil karena kurangnnya latihan fisik.

Berdasarkan observasi yang dilakukan peneliti di PAUD Tunas Mekar Plus Ketika dilakukan observasi pada anak kelompok B yang sedang melakukan kegiatan melompat, kegiatan yang dilakukan yaitu lompat dari keramik satu ke tehel/keramik yang berukuran $40 \mathrm{~cm}$ yang didepannya secara horizontal. Kemudian melakukan lompat tali yaitu hanya dengan menggunakan seutas tali sebagai media anak melompat dengan dengan ketinggian $30 \mathrm{~cm}$, ketika anak melakukan kegiatan melompat, masih ditemukan 6 anak atau $46 \%$ dari 13 anak kurang baik melakukan lompatan.

Guru lebih banyak melakukan kegiatan motorik kasar di ruang kelas. Anak-anak yang sering melakukan bermain sendiri di luar kelas, guru jarang mengamati aktivitas anak yang berkaitan dengan gerakan anak untuk mengembangkan kekuatan dan keseimbangannya. Oleh karena itu, untuk mengoptimalkan kemampuan motorik ini diperlukan adanya kegiatan yang sesuai. Unsur yang menunjang kemampuan motorik kasar khususnya komponen kekuatan dan keseimbangan kurang diperhatikan oleh guru. Upaya 
yang sudah dilakukan guru untuk meningkatkan komponen fisik motorik kasar untuk kekuatan dan keseimbangan dilakukan senam rutin setiap hari Sabtu dalam seminggu, selain itu dalam proses pembelajaran guru mengajak anak melakukan gerakan-gerakan berupa pemanasan, memantulkan bola besar dan bola kecil, serta adanya permainanpermainan yang lain. Oleh karena itu, untuk mengoptimalkan kemampuan motorik ini dilakukan kegiatan yang sesuai, agar menunjang kemampuan motorik kasar khususnya komponen kekuatan dan keseimbangan masih kurang diperhatikan oleh guru.

Berdasarkan masalah yang telah ditemukan pada saat observasi, maka peneliti menentukan cara untuk meningkatkan kemampuan motorik kasar anak dengan menggunakan media atau permainan. Kegiatan yang dilakukan untuk meningkatkan kemampuan motorik kasar khususnya komponen fisik-motorik kekuatan dan keseimbangan anak Kelompok B Paud Tunas Mekar Plus adalah dengan Permainan Tradisional Lompat Tali.Oleh karena itu, ada keinginan peneliti untuk meneliti "Meningkatkan Kemampuan Motorik Kasar Melalui Permainan Tradisional Lompat Tali Pada Usia 5-6 Tahun di" Paud Tunas Mekar Plus Tahun Pelajaran 2017/2018.

\section{METODOLOGI PENELITIAN}

\section{Desain Penelitian}

Jenis penelitian ini termasuk jenis penelitian Tindakan Kelas (PTK), Penelitian tindakan kelas adalaha penelitian yang dilakukan terhadap perilaku dan tindakan yang muncul di dalam proses pembelajaran yang berlangsung di kelas. PTK dilaksanakan sebagai usaha untuk meningkatkan kualitas pmembelajaran yang dilakukan guru di kelas, serta untuk memahami aspek-aspek yang berkenaan dengan peserta didik dan lingkungan yang ada di sekitar kelas. PTK tidak mengganggu proses pembelajaran karena dilakukan dalam proses pembelajaran yang dialami di kelas, sesuai dengan jadwal pembelajaran (Arikunto dalam Zulfaidah Indriana 2013 : 2). PTK bersifat situasional, kontekstual berskala kecil, terlokalisasi dan secara relevan langsung berhubungan dengan situasi nyata di dalam kelas. PTK melibatkan peserta didik dan kolaborator sebagai mitra guru. Dalam Sulifan (2007:18) Peneliti Tindakan Kelas berbentuk siklus, setiap siklus terdiri dari 4 (empat) tahap yaitu : perencanaan, pelaksanaan, pengamatan dan refleksi. Penelitian tindakan kelas berupa bagaimana memperbaiki kinerja guru dan aktifitas siswa beruhaha untuk meningkatkan keberhasilan belajar siswa sesuai dengan tujuan pembelajaran. Penelitian tindakan kelas 
(PTK) yang dimaksud dengan proses belajar mengajar pada kelompok B Paud Tunas Mekar Plus Samarinda kecematan sungai pinang menggunakan Permainan Tradisional Lompat Tali guna meningkatkan motorik kasar oleh anak kelompok B.

\section{Subyek Penelitian}

Subyek penelitian tindakan kelas ini meliputi seluruh anak Paud Tunas Mekar Plus kelompok B yang meliputi 13 anak yang terdiri dari laki-laki 7 dan 6 perempuan.

\section{Obyek Penelitian}

Obyek penelitian tindakan kelas ini yaitu untuk meningkatkan motorik kasar melalui Permainan Tradisional Lompat Tali pada usia 5-6 tahun di Paud Tunas

\section{Prosedur Penelitian}

Prosedur penelitian dilakuakan 2 siklus, yaitu setiap siklus terdiri dari 3 kali pertemuan yang dilaksankan dengan menggunakan prosedur :

1. Perencanaan.

Pada tahap ini peneliti merumuskan dan mempersiapkan, rencana jadwal pelaksanaan tindakan dengan membuat Rencana Persiapan Pembelajaran (RPPM) dan Rencana Persiapan Pembelajaran Harian (RPPH) yang telah disiapkan sebelum pembelajaran berlangsung dan mempersiapkan kegiatan pembelajaran yang akan diberikan dan dicontohkan kepada anak. 2. Pelaksanaan tindakan.
Pelaksanaan tindakan ini merupakan pelaksanaan tindakn dari persiapan pembelajaran yang telah direncanaka dalam rencana pelaksanaan pembelajaran. Dalam proses pembelajaran dilaksanakan peneliti selaku guru. Rencana kegiatan Mingguan (RKM) dan Rencana Pembelajran Harian (RPPH).

3. Pengamatan.

Pada tahap ini merupakan kegiatan yang dilaksanakan peneliti untuk melakukan pengamatan terhadap aktivitas prosedur belajar setiap siswa. Pengamatan tersbut dilakukan untuk mengenali, mengumpulkan data dari setiap indicator mengenai unjuk kerja siswa dalam proses belajar mengajar, dan objek pengamatan itu adalah hasil kemampuan motorik kasar dengan indikator.

4. Refleksi.

Pada tahap refleksi, peneliti menyimpulkan hasil dari tindakan pada setiap akhir pelaksanaan tindakan yang telah terkumpul kemudian ditindak lanjuti dengan melakukan analisa, sehingga hasil dapat diketahui dari pelaksanaan tindakan yang dilakukan. Sehingga peneliti dapat menyimpulkan untuk siklus berikutnya.

\section{Instrumen Peneltian}

Dalam penelitian ini instrument yang digunakan adalah lembar observasi dan catatan lapangan. Indikator pencapaian keberhasilan kegiatan ini dapat dilihat 
dengan adanya meningkatkan motorik kasar melalui permainan tradisional lompat tali.

\section{Teknik Pengumpulan Data}

Pengumpulan data untuk mengetahui motorik kasar yang digunakan teknik observasi yaitu melakukan pengamatan secara langsung, teliti, cermat dan hati hati. Observasi yang dilakukan meliputi membandingkan hasil pencapaian anak dengan indikator penelitian setiap siklus. Jenis data pembelajaran Permainan Tradisional Lompat Tali adalah :

1. Sumber data adalah anak yang mengikuti pembelajaran Permainan Tradisional Lompat Tali, guru dan media pembelajaran.

2. Pengambilan data dilakukan dengan cara :

a. Pengamatan atau observasi dalam ranggka pengumpulan data dengan mengamati kegiatan permainan lompat tali dan mengumpulkan data dengan mengamati aktifitas guru.

b. Dokumentasi yaitu mendokumentasikan segala kegiatan selama penelitian. Dokumen berupa foto-foto kegiatan proses bermain lompat tali.

\section{Teknik Analisis Data}

Teknik analisis data merupakan teknik yang digunakan untuk menganalisis data hasil penelitian untuk membuktikan hipotesis yang telah dirumuskan. Pada penelitian tindakan kelas analisis data berdasarkan pada observasi kegiatan pembelajaran dan hasil tindakan yang dilakukan analisis data ini digunakan untuk melakukan refleksi agar peneliti dapat mengambil tindakan dalam siklus berikutnya. Data motorik kasar anak di analisis komparatif yang dicapai dengan riil pencapaian pembelajaran pada setiap siklus.

Analis data menggunakan Persentase siswa dihitung berdasarkan perolehan nilai kategori dan dihitung berapa persen untuk setiap kategori. Untuk mencapai Persentase ketuntasan belajar dengan menggunakan rumus :

$$
\text { Persentase }=\frac{a}{b} \times 100 \%
$$

Keterangan :

$\mathrm{a}=$ Jumlah siswa yang memenuhi kriteri $\mathrm{b}=$ Jumlah siswa keseluruhan

( sumber : Sudjana, 2002)

\section{Kriteria penelitian}

Adapun data tentang lembar aktifitas anak menggunakan rumus : $1=$ belum berkembang, $2=$ mulai berkembang, 3 = berkembang sesuia harapan, 4 = berkembang sangat baik. Alat yang digunakan untuk observasi aktivitas anak berupa nilai, yaitu sebagai berikut : 
Tabel 1. Observasi Aktivitas Anak

\begin{tabular}{|c|c|c|c|}
\hline No & $\begin{array}{c}\text { Tingkat } \\
\text { keberhasilan }\end{array}$ & kategori & Kriteria \\
\hline 1 & $<25 \%$ & $\begin{array}{c}\text { Belum } \\
\text { berkembang }\end{array}$ & 1 \\
\hline 2 & $25-59 \%$ & $\begin{array}{c}\text { Mulai } \\
\text { berkembang }\end{array}$ & 2 \\
\hline 3 & $60-79 \%$ & $\begin{array}{c}\text { Berkembang } \\
\text { sesui harapan }\end{array}$ & 3 \\
\hline 4 & $>80 \%$ & $\begin{array}{c}\text { Berkembang } \\
\text { sangat baik }\end{array}$ & 4 \\
\hline
\end{tabular}

\section{Kriteria keberhasilan}

Kriteria keberhasilan penelitian dinyatakan berhasil apabila $75 \%$ jumlah anak memperoleh kriteria nilai adalah $\geq$ berkembang sesui harapan yaitu mendapat angka tiga (3).

\section{Indikator penilaian}

Adapun indikator penilaian yang digunakan adalah sebagai berikut :

1. Kemampuan melompat sambil berlari dengan jarak $40 \mathrm{~cm}(20$ $\mathrm{cm}$ sebelum tali dan $20 \mathrm{~cm}$ sesudah tali).

2. Keseimbangan anak dalam melompat tali.

3. Kemampuan anak melompat ketinggian $30 \mathrm{~cm}$

Tabel 2. Kriteria Penilaian

\begin{tabular}{|c|c|c|}
\hline NO & SKOR & KRITERIA \\
\hline 1 & 4 & Berkembang Sangat Baik (BSB) \\
\hline 2 & 3 & Berkembang Sesuai Harapan (BSH) \\
\hline 3 & 2 & Mulai Berkembang (MB) \\
\hline 4 & 1 & Belum Berkembang (BB) \\
\hline
\end{tabular}

\section{TEMUAN DAN PEMBAHASAN}

\section{Hasil Pengamatan}

\section{Siklus 1}

Berdasarkan penelitian selama pelaksanaan pada siklus 1 inisudah ada peningkatan anak mulai antusias terhadap permainan lompat tali, namun belum mencapai nilai yang diharapkan. sehingga dilanjutkan pada siklus 2 .

Tabel 3. Hasil Pengamatan Anak Dengan Kemampuan BSH dan BSB Siklus 1

\begin{tabular}{|c|c|c|c|c|c|c|}
\hline \multirow{2}{*}{$\begin{array}{c}\text { Aspek } \\
\text { Penilaian }\end{array}$} & \multicolumn{2}{|c|}{ P1 } & \multicolumn{2}{|c|}{$\mathrm{P} 2$} & \multicolumn{2}{|c|}{ P3 } \\
\hline & $\begin{array}{l}\text { Jmlh } \\
\text { anak }\end{array}$ & $\%$ & $\begin{array}{c}\text { Jmlh } \\
\text { anak }\end{array}$ & $\%$ & $\begin{array}{l}\text { Jmlh } \\
\text { anak }\end{array}$ & $\%$ \\
\hline $\begin{array}{c}\text { Berlari } \\
\text { Sambil } \\
\text { Melompat } \\
\text { dari Jari } 40 \\
\mathrm{~cm}\end{array}$ & 2 & $\begin{array}{l}15 \\
\%\end{array}$ & 3 & $\begin{array}{l}23 \\
\%\end{array}$ & 7 & $\begin{array}{l}54 \\
\%\end{array}$ \\
\hline $\begin{array}{c}\text { Keseimbang } \\
\text { an Badan }\end{array}$ & 1 & $8 \%$ & 3 & $\begin{array}{l}23 \\
\%\end{array}$ & 7 & $\begin{array}{l}54 \\
\%\end{array}$ \\
\hline $\begin{array}{c}\text { Meloncat } \\
\text { Dengan } \\
\text { Ketinggian } \\
30 \mathrm{~cm}\end{array}$ & 2 & $\begin{array}{l}15 \\
\% \\
\%\end{array}$ & 4 & $\begin{array}{l}31 \\
\%\end{array}$ & 5 & $\begin{array}{l}34 \\
\%\end{array}$ \\
\hline Rata-rata & & $\begin{array}{l}13 \\
\%\end{array}$ & & $\begin{array}{l}19 \\
\%\end{array}$ & & $\begin{array}{l}47 \\
\%\end{array}$ \\
\hline
\end{tabular}

Aspek penilaian dan proses pembelajaran siklus 1

a. Hasil penilaian siklus 1 pertemuan 1 kemampuan motorik kasar anak dengan aspek penilaian melompat sambil berlari dari jarak $40 \mathrm{~cm}$, keseimbangan melompat dan melompat dengan ketinggian 30 $\mathrm{cm}$, jika dirata-ratakan mencapai hasil 13\%. Hal ini menunjukkan bahwa kemampuan motorik anak belum berkembang dikarenakan anak belum mengenal permainan lompat tali. Anak masih ragu-ragu, kurang percaya diri bahkan tidak mau melakukan lompatan sama sekali.

b. Hasil penilaian siklus 1 pertemuan 2 kemampuan motorik kasar anak dengan aspek penilaian melompat sambil berlari dari jarak $40 \mathrm{~cm}$, keseimbangan melompat dan melompat dengan ketinggian 30 $\mathrm{cm}$, jika dirata-ratakan mencapai hasil 19\%. Hal ini menunjukkan 
bahwa kemampuan motorik anak mulai berkembang anak sudah mulai mau melakukan permainan lompat tali.

c. Hasil penilaian siklus 1 pertemuan 3 kemampuan motorik kasar anak dengan aspek penilaian melompat sambil berlari dari jarak $40 \mathrm{~cm}$, keseimbangan melompat dan melompat dengan ketinggian 30 $\mathrm{cm}$, jika dirata-ratakan mencapai hasil $47 \%$. Hal ini menunjukkan bahwa kemampuan motorik anak mulai berkembang anak sudah mulai mau dan tertarik melakukan permainan lompat tali.

d. Hasil penilaian siklus 1 pertemuan 1, 2 dan 3 penilaian aktifitas guru dalam hal ini adalah:

1) Guru sulit mengkondisikan anak ketika berbaris. Anak keluar barisan dan berlari-lari.

2) Guru memberikan penjelasan melompat hanya pada awal akan dilakukan saja. Pemberian contoh atau demontrasi hanya dilakukan sekali sebelum anak-anak melakukan lompat

3) Guru kurang memberikan reward kepada anak sehingga anak kurang motivasi anak sehingga kemampuan anak melakukan permainan lompat tali belum mencapai target yang diharapkan sehingga perlu diadakan tindakan lebih lanjut yaitu pelaksanaan siklus 2 .

\section{Siklus 2}

Berdasarkan penelitian selama pelaksanaan pada siklus 2 telah terjadi peningkatan seknifikan dan dapat dikatakan telah mencapai nilai yang diharapkan Adapun aspek-aspek dalam penilaian dan proses pembelajaran siklus 2.

1. Hasil penilaian siklus 2 pertemuan 1 kemampuan motorik kasar anak dengan aspek penilaian melompat sambil berlari dari jarak $40 \mathrm{~cm}$, keseimbangan melompat dan melompat dengan ketinggian 30 $\mathrm{cm}$, jika di rata-ratakan mencapai hasil 52\%. Hal ini menunjukan kemampuan motorik kasar anak dalam permainan lompat tali semakin meningkat dikarenakan anak-anak semakin senang mengikuti permainan lompat tali namun hasil kemampuan motorik anak belum mencapai nilai ketuntasan dan dilanjutkan pada pertemuan ke 2 .

2. Hasil penilaian siklus 2 pertemuan 2 kemampuan motorik kasar anak dengan aspek penilaian melompat sambil berlari dari jarak $40 \mathrm{~cm}$, keseimbangan melompat dan melompat dengan ketinggian 30 $\mathrm{cm}$, jika di rata-ratakan mencapai hasil $58 \%$ mengalami peningatan lagi.dikarenakan anak-anak mulai 
suka dan serius melakukan permainan lompat tali namun hasil kemampuan motorik anak belum mencapai nilai ketuntasaan sehinnga dilanjutkan ke pertemuan ke 3.

3. Hasil penilaian siklus 2 pertemuan 3 kemampuan motorik kasar anak dengan aspek penilaian melompat sambil berlari dari jarak $40 \mathrm{~cm}$, keseimbangan melompat dan melompat dengan ketinggian 30 $\mathrm{cm}$, jika di rata-ratakan mencapai hasil $77 \%$. Hal ini menunjukan bahwa kemampuan motorik anak dalam permaina lompat tali semakin ada peningkatan yang maksimal. ini dikarenakan anak semakin suka, serius, dan aktif dalam melakukan permainan lompat tali sehingga hasil yang diperoleh sesuai dengan nilai yang diharapkan.

4. Hasil penilaian siklus 1 pertemuan 1, 2 dan 3 penilaian aktifitas guru dalam hal ini adalah:

a. guru sudah bisa mengkondisikan anak ketika berbaris. Sehingga anak tidak keluar barisan dan berlari-lari.

b. Guru memberikan penjelasan kepada anak tidak hanya diawal kegiatan, tetapi diselasela ketika anak melakukan kegiatan. c. Guru memberikan motivasi berupa reward stiker gambar kepada anak setelah anak melakukan kegiatan lompat tali. sehingga anak dapat melakukan permainan lompat tali pada kelas B sudah mencapai nilai yang diharapkan.

Tabel 4. Hasil Pengamatan Anak Dengan Kemampuan BSH dan BSB Siklus 2

\begin{tabular}{|c|c|c|c|c|c|c|}
\hline \multirow{2}{*}{$\begin{array}{c}\text { Aspek } \\
\text { Penilaian }\end{array}$} & \multicolumn{2}{|c|}{ P1 } & \multicolumn{2}{|c|}{ P2 } & \multicolumn{2}{|c|}{ P3 } \\
\hline & $\begin{array}{c}\begin{array}{l}\text { Jmlh } \\
\text { anak }\end{array} \\
\end{array}$ & $\%$ & $\begin{array}{l}\text { Jmlh } \\
\text { anak }\end{array}$ & $\%$ & $\begin{array}{c}\text { Jmlh } \\
\text { ank }\end{array}$ & $\%$ \\
\hline $\begin{array}{c}\text { Berlari } \\
\text { Sambil } \\
\text { Melompat } \\
\text { dari Jari } 40 \\
\mathrm{~cm}\end{array}$ & 9 & $\begin{array}{l}69 \\
\%\end{array}$ & 9 & $\begin{array}{l}69 \\
\%\end{array}$ & 11 & $\begin{array}{l}85 \\
\%\end{array}$ \\
\hline $\begin{array}{l}\text { Keseimban } \\
\text { gan Badan }\end{array}$ & 8 & $\begin{array}{l}62 \\
\%\end{array}$ & 8 & $\begin{array}{l}62 \\
\%\end{array}$ & 10 & $\begin{array}{l}77 \\
\%\end{array}$ \\
\hline $\begin{array}{c}\text { Meloncat } \\
\text { Dengan } \\
\text { Ketinggian } \\
30 \mathrm{~cm}\end{array}$ & 6 & $\begin{array}{l}46 \\
\%\end{array}$ & 7 & $\begin{array}{l}54 \\
\%\end{array}$ & 10 & $\begin{array}{l}77 \\
\%\end{array}$ \\
\hline Rata-Rata & & $\begin{array}{l}59 \\
\%\end{array}$ & & $\begin{array}{l}62 \\
\%\end{array}$ & & $\begin{array}{l}80 \\
\%\end{array}$ \\
\hline
\end{tabular}

\section{Pembahasan Hasil Penelitian}

Kemampuan motorik kasar merupakan salah satu aspek yang penting untuk perkembangan dan pertumbuhan anak. Pertumbuhan anak usia dini sangat bergantung terhadap kemampuan motorik kasar yang dilakukannya. Penelitian ini merupakan penelitian tindakan kelas yang terdiri dari 2 Siklus yaitu Siklus I dan Siklus II yang dilakukan sebanyak 3 kali pertemuan setiap Siklus. Pada awal dilakukan observasi kemampuan motorik kasar dengan kreteria melompat sambil berlari dari jarak $40 \mathrm{~cm}$, keseimbangan badan dan melompat dari ketinggian $30 \mathrm{~cm}$ masih kurang baik. 
Ketika dilakukan pra tindakan terdapat $15 \%$ dari kreterian nilai berkembang sesuai harapan (3). anak tidak mau untuk melakukan gerakan motorik kasar, kebanyakan dari mereka berlarilarian atau mengganggu teman. Anak yang mau melakukan harus dibantu oleh guru.

Kegiatan motorik kasar yang dilakukan oleh guru masih kurang menarik dan pelaksanaannya masih didalam kelas sehingga anak kurang leluasa dan masih malas-malasan untuk melakukan. Gerakan motorik kasar tidak dilakukan di awal pembelajaran, akan tetapi sefleksibel guru untuk memberikan kegiatan motorik kasar tersebut. Terdapat beberapa anak yang kurang bisa untuk menirukan gerakan motorik kasar, beberapa anak tidak bisa melakukan. Dengan adanya kegiatan lompat tali dalam kegiatan motorik kasar anak diharapkan mampu untuk menigkatkan kebugaran jasmani anak yaitu kekuatan dan keseimbangan.

Berdasarkan hasil observasi pra tindakan yang dilaksanakan tanggal 17 Juli 2017 menunjukkan bahwa kemampuan motorik kasar anak dengan kreteria melompat sambil berlari dari jarak $40 \mathrm{~cm}$, keseimbangan badan dan melompat dari ketinggian $30 \mathrm{~cm}$ masih kurang baik. Anak masih belum mau melakukan lompatan, dan beberapa anak masih menyentuh tali, dan terjatuh setelah melakukan lompatan. Dilihat dari hasil pratindakan tersebut maka masih perlu ditingkatkannya kemampuan motorik kasar anak. Diperlukan kegiatan yang sederhana dan menarik untuk mengajak anak agar terlibat langsung didalamnya, kegiatan yang menyenangkan dan membuat anak untuk selalu ingin mengulanginya. Kegiatan tersebut adalah lompat tali. Dalam penelitian ini peningkatan kemampuan motorik kasar anak melalui lompat tali secara sederhana dan menyenangkan. Kegiatan lompat tali dapat dilakukan dengan baik oleh anak Kelompok B Paud Tunas Mekar Plus dengan ketinggian $30 \mathrm{~cm}$. Hal ini sependapat dengan Bambang Sujiono (2005: 3.23) yang menyatakan bahwa anak dapat melompat dari ketinggian $\leq 60-70 \mathrm{~cm}$ dan melompati tali yang tingginya $30 \mathrm{~cm}$. Hal ini dikarenakan ketika anak diminta untuk lompat tali dengan

Hurlock (1978:320) bermain merupakan setiap kegiatan yang dilakukan untuk kesenangan yang ditimbulkan tanpa mempertimbangkan hasi akhir. Pendapat tersebut sama halnya dengan pendapat Mayke. S Tedjasaputra (2001: 11) menyatakan bahwa bermain memungkinkan anak untuk bereksplorasi terhadap kemungkinan yang ada untuk meningkatkan kemampuan motorik kasar maka dilakukan dengan kegiatan yang menyenangkan, sehingga secara 
tidak langsung anak tertarik dan menikmati permainan atau kegiatan tersebut. Kegiatan lompat tali merupakan kegiatan yang sangat sederhana untuk dilakukan anak agar anak merasa senang. Hal ini sependapat dengan Hurlock (1996) yang menyatakan bahwa keterampilan motorik anak dapat menghibur dirinya untuk memperoleh perasaan senang seperti memainkan tali. Dengan kegiatan lompat tali, otot-otot kaki anak menjadi kuat, serta melatih keseimbangan anak dalam melakukan gerakan. Kegiatan sederhana ini tidak membuat anak bosan karena anak selalu ingin mengulanginya dan membuat anak menjadi lebih percaya diri. Pernyataan tersebut sesuai dengan pendapat Sumantri (2005: 70) menyatakan bahwa peningkatan motorik terjadi sejalan dengan meningkatnya kemampuan koordinasi mata, tangan, dan kaki. perkembangan motorik bisa terjadi dengan baik apabila anak memperoleh kesempatan yang cukup besar untuk melakukan aktivitas fisik dalam bentuk gerakan-gerakan yang melibatkan seluruh tubuh.

Berdasarkan hasil pelaksanaan tindakan Siklus I dapat terlihat perolehan anak mengalami peningkatan yaitu $47 \%$ anak berada pada kriteria berkembang sesuai harapan (3). Berdasarkan hasil data tersebut maka dilaksanakan perbaikan tindakan selanjutnya karena belum mencapai indicator keberhasilan yang ditetapkan yaitu $80 \%$. Beberapa kendala yang ditemui pada Siklus I yaitu guru kurang mampu mengkondisikan anak, sehingga banyak anak yang berlarian sendiri. Kesempatan yang dimiliki anak hanya sekali. Anak yang sudah melakukan kegiatan mengganggu teman lain yang belum melakukan. Kurangnya motivasi yang diberikan oleh guru dan kekuaan otot kaki anak yang belum optimal. Kendala Siklus I mampu teratasi di Siklus II. Sebelum kegiatan dilakukan anak melakukan pemanasan dengan gerakan sederhana. Agar kondusif guru memecah barisan menjadi dua barisan, kondisi anak sudah mampu dikontrol oleh guru dan sudah kondusif seperti yang diharapkan. Anak yang sebelumnya tidak mau melakukan lompat tali, hanya mau melihat saja perlahan menjadi mau melakukan. Guru berulang kali memberikan contoh agar kekuatan anak dalam melompat optimal, dan ketika mendarat setelah melompat keseimbangan anak baik motivasi serta reward yang diberikan ke anak untuk menunjang semangat dan tertarik terhadap kegiatan tersebut. Berdasarkan hasil penelitian pada Siklus II menunjukkan bahwa sebanyak $80 \%$ anak sudah mencapai nilai ketuntasan yaitu berkembang sesai harapan (3). Dari hasil yang diperoleh tersebut dapat diketahui adanya peningkatan pada 
kemampuan motorik kasar anak Kelompok B Paud Tunas Mekar Plus Pemberian reward pada Siklus II berupa stiker bergambar sangat efektif untuk menunjang semangat dan rasa percaya diri anak untuk melakukan lompat tali. Motivasi yang diberikan juga berupa lisan kepada setiap anak sebelum maju diberi motivasi oleh guru.

Berdasarkan hasil observasi sebelum tindakan, Siklus I, dan Siklus II, maka diperoleh hasil peningkatan yang sedemikian rupa dari indikator yang sudah ditentukan. Dengan demikian dapat dikatakan bahwa melalui kegiatan lompat tali dapat meningkatkan kemampuan motorik kasar anak khususnya unsur kekuatan dan keseimbangan tubuh anak. Berdasarkan hasil penelitian sejalan dengan pendapat Bambang Sujiono (2005: 6.25) mengatakan dengan melakukan lompat dapat meningkatkan kekuatan dan kecepatan otot-otot tungkai. Manfaat lain adalah kegiatan lompat tali ini menyenangkan untuk anak dan tidak memiliki resiko bahaya yang besar, sehingga kemampuan motorik kasar anak dapat berkembang dengan baik.

\begin{tabular}{|l|c|c|}
\multicolumn{1}{|c|}{ Tabel. 4.5 Aspek Penilian } \\
\hline $\begin{array}{c}\text { Aspek } \\
\text { Penilaian }\end{array}$ & $\begin{array}{c}\text { Siklus } \\
1\end{array}$ & $\begin{array}{c}\text { Siklus } \\
2\end{array}$ \\
\hline $\begin{array}{l}\text { Berlari Sambil } \\
\text { Melompat dari } \\
\text { Jari 40 cm }\end{array}$ & $54 \%$ & $85 \%$ \\
\hline $\begin{array}{l}\text { Keseimbangan } \\
\text { Badan }\end{array}$ & $54 \%$ & $77 \%$ \\
\hline $\begin{array}{l}\text { Meloncat } \\
\text { Dengan } \\
\text { Ketinggian 30 } \\
\text { cm }\end{array}$ & $38 \%$ & $77 \%$ \\
\hline
\end{tabular}

\begin{tabular}{|l|l|l|}
\hline Rata-Rata & $47 \%$ & $80 \%$ \\
\hline
\end{tabular}

\section{PENUTUP}

\section{Kesimpulan}

Berdasarkan hasil penelitian dan pembahasan dapat disimpulkan bahwa kemampuan motorik kasar anak kelompok B Paud Tunas Mekar Plus yang terjadi dapat terlihat dari tahap penelitian, yaitu observasi yang dilakukan saat pratindakan, pelaksanaan tindakan pada Siklus I dan Siklus 2. Langkah-langkah yang ditempuh dalam kegiatan lompat tali ini adalah guru mempersiapkan tempat yang akan digunakan, kemudian mempersiapkan alat yang akan digunakan. Anakdikondisikan berbaris menjadi dua barisan. Kemudian guru memberikan intruksi kepada anak cara melakukan dan memberikan contoh melompat yang benar. Kegiatan lompat tali ini dilakukan menjadi dua kelompok,setiap anak melompat satu persatu dari anak yang berbaris paling depan hingga anak terkahir. Setiap anak diberi dua kali kesempatan untuk melompat pada tali. Kegiatan diawali dengan melakukan nyanyian dan gerakangerakan pemanasan agar otot kaki anak kuat, tubuh tidak kaku dan semangat. Pemberian reward juga dilakukan untuk menunjang semangat dan percaya diri anak, diberikan pada setiap anak yang mau melakukan lompat. Komponen fisik motorik kasar, kekuatan dan 
keseimbangan melalui lompat tali mampu meningkat dengan baik. Hal ini ditandai oleh peningkatan presentase ketuntasan nilai 3 (berkembang sesuai harapan) yaitu dari semula $15 \%$ pada hasil observasi pra tindakan, menjadi 47\% pada siklus 1 kemudian menjadi $80 \%$ pada siklus 2 .

\section{Saran}

Dalam kesempatan ini, peneliti ingin memberikan saran - saran kepada Pengelola PAUD :

1. Tunas Mekar Plus samarinda yaitu bahwa hasil penelitian ini sebagai acuan untuk meningkatkan motorik kasar anak

2. Bagi Pendidik PAUD. Pelaksanaan kegiatan lompat tali atau kegiatan yang berkaitan dengan motorik kasar yang diberikan guru kepada anak-anak sebaiknya dilakukan pemanasan terlebih dahulu. Guru lebih giat memberikan motivasi kepada anak, agar anak tetap bersemangat dan anak mampu lebih percaya diri ketika melakukan kegiatan lompat tali atau kegiatan yang berkaitan dengan motorik kasar.

3. Bagi Peneliti Selanjutnya, Kegiatan lompat tali ini yang dilakukan dapat dijadikan sebagai referensi lebih disempurnakan kembali. Kegiatan lompat tali dapat divariasi kembali tidak menggunakan satu tali tetapi menggunakan 2 atau 3 tali dengan variasi ketinggian berbeda. Komponen motorik yang diteliti juga dapat dikembangkan kembali, tidak hanya kekuatan dan keseimbangan, tetapi kelincahan dan kelentukan dapat dijadikan komponen penelitian selanjutnya.

\section{DAFTAR PUSTAKA}

Ali hamdani. 2014. Makalah karakteristik pendidikan anak, (online),

http//hamdanial.blogsport.co.id/2 014/04/makalah-karakteristikpendidikan anak.html=1, di askes 13 Otober 2017)

Indriana Zulfaidah 2013. Pengertian dan karakteristik penelitian Tindakan Kelas.(http://zulfaidahindriana.blogspot.com/2013/05/p engertian-dankarakteristik penelitian.html?=1, diakses 24 juli 2017)

Mansyur. 2005. Pendidikan Anak Usia Dini Dalam Islam. Yogyakarta: Pustaka Pelajar. Mayke S Tedjasaputra. 2001. Bermain, Mainan, dan Permainan. Jakarta: PT Gramedia Widiasarana Indonesia.

Muhammad Fadillah dan Lilif Mualifatu Khorida. 2013. Pendidikan Karakter Anak Usia Dini: Konsep dan Aplikasinya dalam PAUD. Yogyakarta: ArRuzz Media

Nelfa Rolina, Santrock. 2012. Alat Permainan Edukatif Anak Usia Dini. Yogyakarta: Penerbit Ombak.Misbach, Mulyani Novi (2016). Super Asyik permainan Tradisional. Diva Press: Yogyakarta 
Mulyani Novi (2016). Super Asyik permainan Tradisional. Diva Press :Yogyakarta

Nelfa Rolina, Santrock. (2012). Alat Permainan Edukatif Anak Usia Dini. Yogyakarta: Penerbit Ombak.

Pusat Bahasa Departemen Pendidikan Nasional. (2007). Kamus Besar Bahasa Indonesia Jakarta: Balai Pustaka.

Richard D, Hurlock, (2017). Panduan Mengembankan Kecerdasan Motorik Siswa. Yogyakarta :Diva Press Samsudin. 2008. Pembelajaran Motorik di Taman Kanak-Kanak. Jakarta: Prenada Media Group. Sari Indah Pravista, Gallahue 2015 Upaya meningkatkan motorik kasar anak melalui lompat tali (eprints.uny.ac.id /23969/1/pravista\% 20indah\%20saridiakses 24 juli 2017)

Sari Indah Pravista, Santrock 2015 Upaya meningkatkan motorik kasar anak melalui lompat tali(eprints.uny.ac.id/23969/1/pra vista\%20indah\%20saridiakses 24 juli 2017) Sujiono Bambang et al. 2008. Metode Pengembangan Fisik. Jakarta: Universitas Terbuka

Sulifan 2007. Classroom Action Research Tehnik Penulisan dan Contoh Proposal PTK Rahayas. Jakarta : Rineka Cipta

Sumantri. 2005. Model Pengembangan Keterampilan Motorik Anak Usia Dini.Jakarta: Depdikbud

Yunus Ahmad, Mulyani Novi (2016). Super Asyik permainan Tradisional. Diva Press :Yogyakarta http://portalkurikulum.blogspot.co.id/20 16/08/faktor-faktor-yangmempengaruh Faktor-faktor yang mempengaruhi perkembangan motorik anak usia dini PAUDi.html. diakses 24 Agustus 2017

http://amisisiliasari.blogspot.co.id/2012/ 12/perkembangan-motorik-kasaranaktk.html diakses 24 Agustus 2017 
